\title{
Optimasi Sifat-Sifat Fisis Lapisan Tipis a-SiGe:H dengan Metoda HW-Cell-PECVD
}

\author{
D. Adisaputra dan Satwiko Sidopekso* \\ Jurusan Fisika, Universitas Negeri Jakarta \\ Jl. Rawamangun Muka, Jakarta 13220 \\ T. Winata \\ Laboratorium Fismatel, Departemen Fisika, Institut Teknologi Bandung \\ Jl. Ganesa 10, Bandung 40132
}

\begin{abstract}
Intisari
Metode Hot Wire Cell PECVD (Plasma Enhanced Chemical Vapor Deposition) telah berhasil dikembangkan untuk menumbuhkan lapisan tipis amorf silikon germanium terhidrogenasi (a-SiGe:H). Lapisan tipis a-SiGe:H ditumbuhkan di atas gelas corning 7059 pada temperatur filamen $800^{\circ} \mathrm{C}$. Campuran gas silan $\left(\mathrm{SiH}_{4}\right) 10 \%$ dalam gas hidrogen $\left(\mathrm{H}_{2}\right)$ dan german $\left(\mathrm{GeH}_{4}\right) 10 \%$ dalam gas hidrogen $\left(\mathrm{H}_{2}\right)$ digunakan sebagai sumber gas. Dalam metode hot wire cell PECVD, gas reaktan didekomposisi dengan filamen tungsten panas yang diletakkan diluar kedua elektroda dan paralel dengan sistem gas masukan. Dan ditumbuhkan juga dengan metoda PECVD (Plasma Enhanced Chemical Vapor Deposition)sebagai pembanding. Dari hasil karakterisasi diperoleh bahwa laju deposisi meningkat dari $0,31 \dot{A}$ /s sampai $1,31 \dot{A}$ /s dengan meningkatnya tekanan deposisi dari 200 sampai 500 mTorr. Celah pita optik meningkat dari $1,42 \mathrm{eV}$ sampai $1,65 \mathrm{eV}$ dengan meningkatnya meningkatnya tekanan deposisi dari 200 sampai 500 mTorr. Dengan sensitivitas penyinaran pada orde $10^{5}$, lebih baik dari metoda PECVD yang memiliki nilai maksimal $1.33 \times 10^{4}$.
\end{abstract}

KATA KUNCI: a-SiGe:H; Sensitivitas; dan Hot Wire Cell PECVD

\section{PENDAHULUAN}

Saat ini material semikonduktor yang paling banyak digunakan sebagai lapisan i untuk sel surya adalah silikon sel tunggal dan silikon polikristal (c-Si dan poli-Si) yang ditumbuhkan di atas substrat silikon pada temperatur yang sangat tinggi $\left(>1000^{\circ} \mathrm{C}\right)$. Tebalnya substrat yang ditumbuhkan $(200-400 \mu)$ dan tingginya temperatur penumbuhan, menyebabkan biaya produksi sel surya tersebut menjadi tinggi, untuk itu diperlukan pengembangan material lain dengan biaya produksi rendah yaitu amorf silikon terhidrogenasi (a-Si:H). Hal inilah yang menjadikan material a-Si:H masih menarik untuk dikaji hingga saat ini [1].

Silikon germanium amorf terhidrogenasi (a-SiGe:H) merupakan salah satu paduan yang cukup baik sebagai penyerap optik (optical absorber) sel bawah untuk sel surya multi junction, karena Eopt nya dapat dikontrol atau dipersempit sesuai dengan panjang gelombang spektrum solar dengan menambah atom Ge [2]. Akan tetapi performa fotoelektronik dari material ini terus menurun dengan bertambahnya atom germanium.

Metoda yang paling umum digunakan untuk menumbuhkan lapisan tipis a-Si:H adalah metoda $r f$ glow discharge dengan menggunakan sistim Plasma Enhanced Chemical Vapor Deposition (PECVD). Dengan sistim ini kandungan hidrogen aSi:H sekitar 10-20\% [3].

Selain itu ada metoda yang relatif baru, Hot Wire Cell

*E-MAIL: sidopekso61@yahoo.com.au
PECVD. Secara umum metoda ini sama dengan PECVD konvensional. Hanya saja ditambahkan filamen panas untuk mendisosiasi gas silan menjadi radikal terlebih dahulu. Filamen diletakkan paralel dengan sistem gas masukkan sejajar dengan elektroda. Untuk mengurangi kandungan hidrogen dapat dilakukan dengan menggunakan temperatur penumbuhan yang tinggi, namun dihasilkan pula tingkat kecacatan yang tinggi. Dengan Hot Wire Cell PECVD temperatur penumbuhan rendah sehingga diharapkan bisa didapat kualitas lapisan yang baik dengan optimasi tekanan penumbuhannya.

\section{EKSPERIMEN}

Lapisan tipis a-SiGe:H dalam studi ini ditumbuhkan di atas gelas corning 7059 dengan menggunakan sistem PECVD dan HW-Cell- PECVD yang ada di Laboratorium Fisika Material Departemen Fisika, ITB. Sistem HWCell- PECVD yang terdiri dari chamber stainless stell berdiameter 8 inci dengan kevakuman sekitar -30 mTorr.

Di dalam chamber ditambahkan filamen dari kawat tungsten dengan diameter 1,2 mm diletakkan sejajar dengan substrat dan terintegrasi dengan sistem gas masukan. Kawat tungsten dibuat berbentuk spiral (lilitan) dengan diameter 5,0 $\mathrm{mm}$ dan panjang $20 \mathrm{~mm}$. Agar dapat berfungsi sebagai hot-wire, filamen dipanaskan dengan menggunakan sumber arus tetap [4].

Parameter penumbuhan adalah seperti terlihat pada Tabel 1. Celah pita optik dihitung dengan metoda tauc-plot dari data 
TABEL I: Parameter penumbuhan lapisan tipis

\begin{tabular}{lcc}
\hline \hline Parameter & Kondisi PECVD & $\begin{array}{c}\text { Kondisi } \\
\text { HW-Cell-PECVD }\end{array}$ \\
\hline Temperatur filamen & - & $800^{\circ} \mathrm{C}$ \\
Temperatur substrat & $200^{\circ} \mathrm{C}$ & $200^{\circ} \mathrm{C}$ \\
Tekanan deposisi & $200-700 \mathrm{mTorr}$ & $200-700 \mathrm{mTorr}$ \\
Daya rf & $50 \mathrm{watt}$ & $50 \mathrm{watt}$ \\
Laju aliran gas: & & \\
SiH4 & $70 \mathrm{sccm}$ & $70 \mathrm{sccm}$ \\
GeH4 & $1 \mathrm{sccm}$ & $1 \mathrm{sccm}$ \\
\hline \hline
\end{tabular}

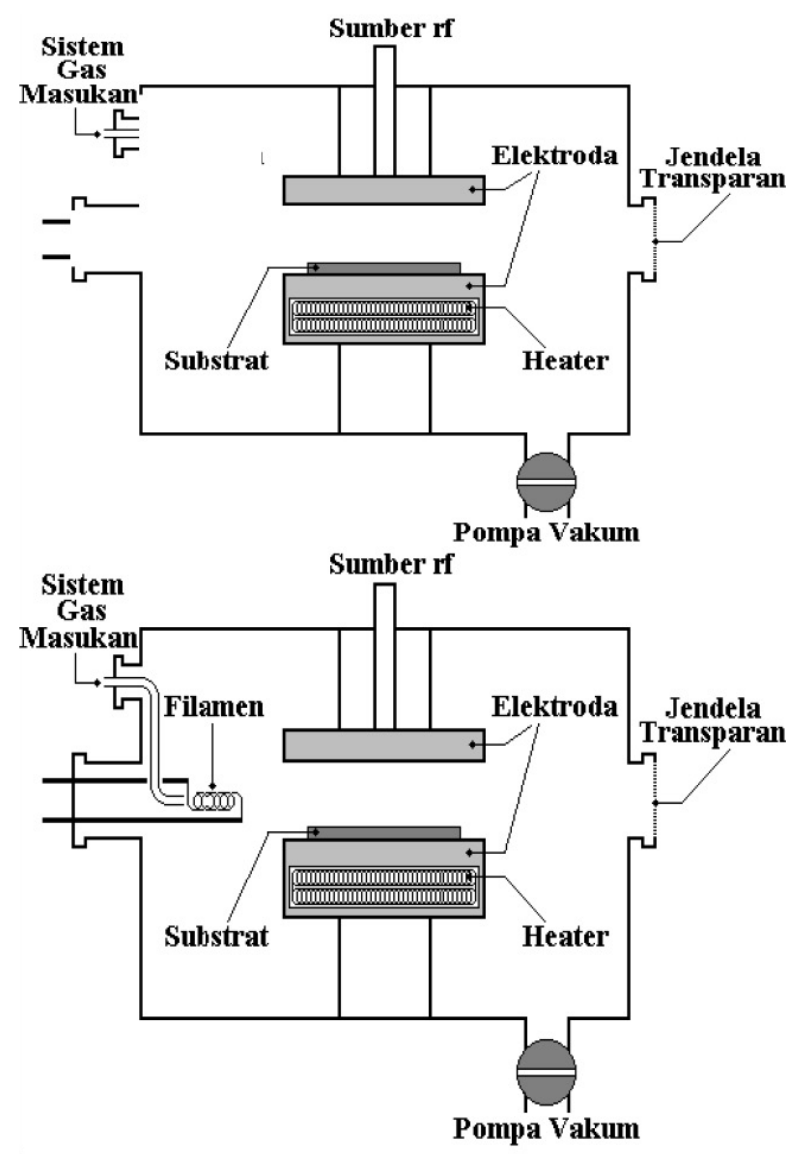

Gambar 1: Skema konfigurasi chamber pada teknik PECVD dan HW-Cell-PECVD

UV-Vis, laju deposisi juga didapat dengan mengunakan stylus Dektak II. Sensitivitasnya didapat dari pengukuran konduktivitas terang-gelapnya dengan metoda coplanar dengan menggunakan Ketheley 617.

Untuk perbedaan konfigurasi chamber pada PECVD dan HW-Cell-PECVD dapat dilihat pada Gambar 1.

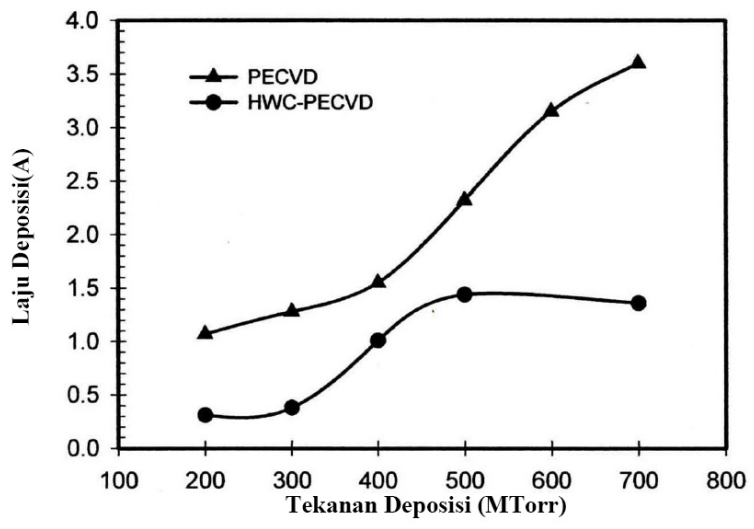

Gambar 2: Laju Deposisi sebagai fungsi tekanan deposisi

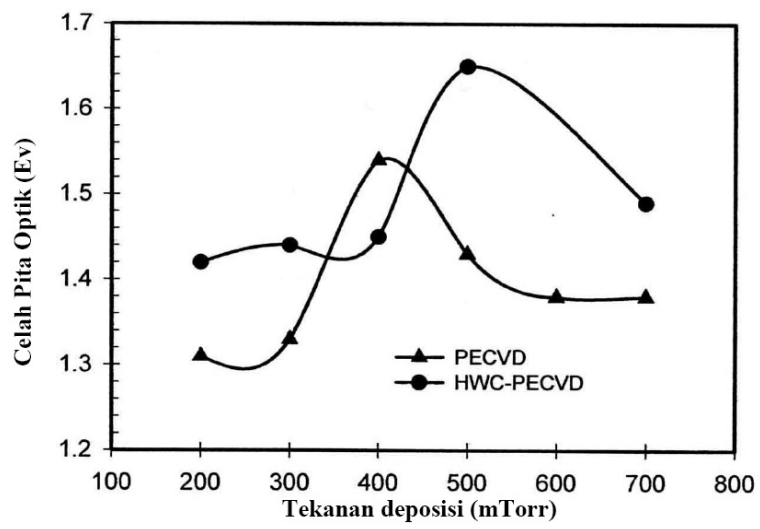

Gambar 3: Celah pita optik lapisan tipis a-SiGe:H

\section{HASIL DAN PEMBAHASAN}

\section{A. Laju deposisi}

Laju deposisi ditentukan dengan mengukur ketebalan lapisan dengan menggunakan stylus Dektak IIA. Laju deposisi a-SiGe:H yang ditumbuhkan dengan metoda PECVD meningkat dari 1,07 sampai $3,06 \dot{A}$ /s dengan meningkatnya tekanan deposisi dari 200 - 700 mTorr. Untuk lapisan yang ditumbuhkan dengan HW-Cell-PECVD, laju deposisi meningkat dari 0,31 1,36 $\dot{A}$ /s antara 200500 mTorr. Selanjutnya cenderung konstan antara 500700 mTorr. Meningkatnya laju deposisi disebabkan oleh berkurangnya jalan bebas rata-rata dari partikel dalam plasma, sehingga laju tumbukan partikel meningkat. Dengan demikian, laju difusi spesies radikal juga meningkat, ditunjukkan pada Gambar 2.

\section{B. Celah pita Optik}

Penentuan celah pita optik lapisan dapat ditentukan melalui spektrum transmitansi UVVis- NIR dengan metoda Tauc plot. Variasi optik terhadap pengaruh tekanan deposisi dapat dilihat pada Gambar 3. Pada Gambar 3 terlihat bahwa celah pita op- 


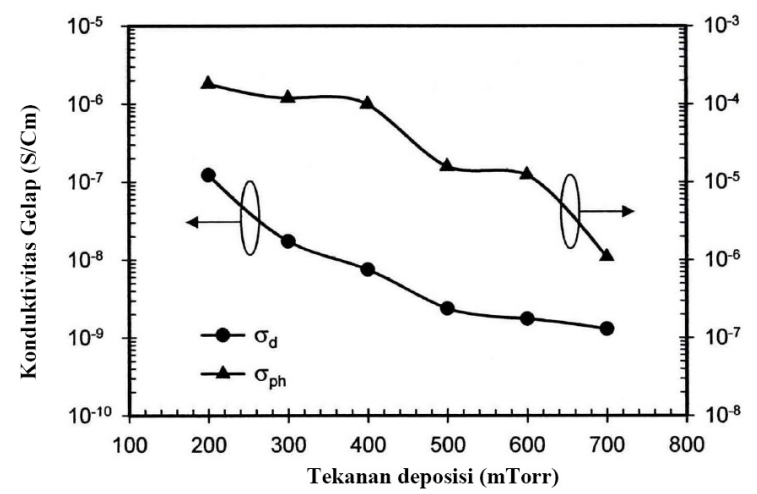

(a)metoda PECVD

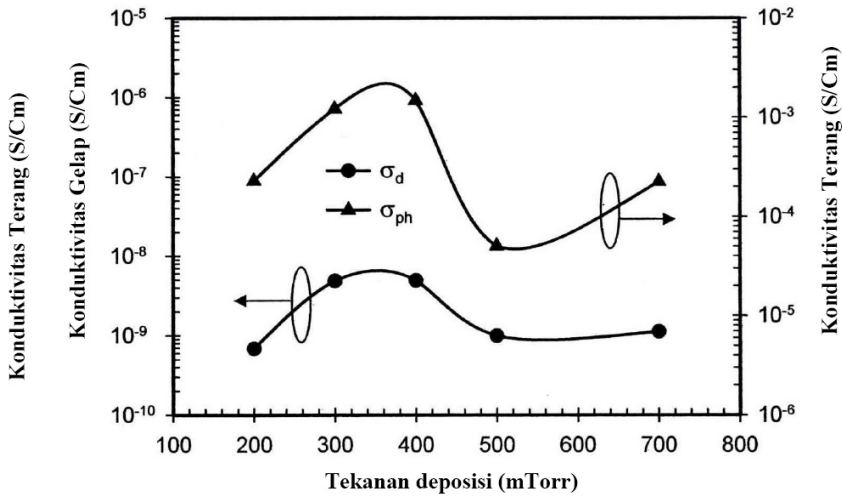

(b)metoda HW-Cell-PECVD

Gambar 4: Konduktivitas sebagai fungsi tekanan

Gambar 5: Celah pita optik lapisan tipis a-SiGe:H

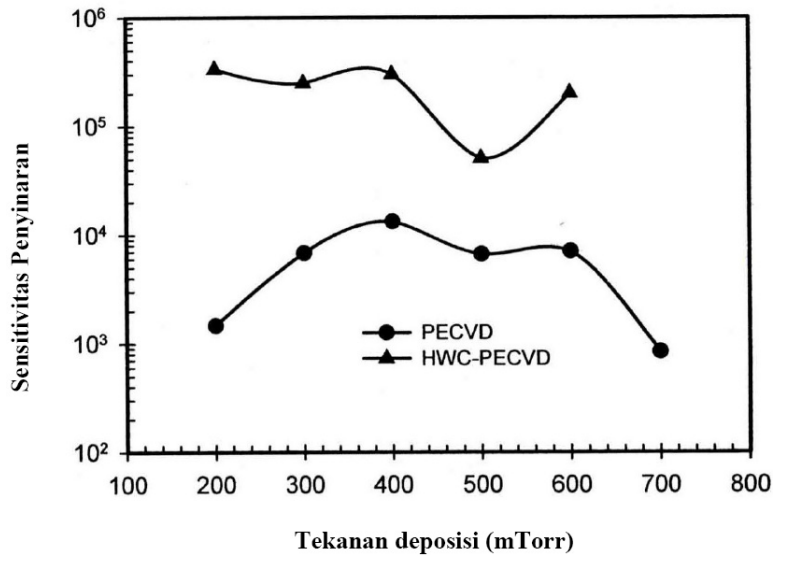

a-SiGe:H yang ditumbuhkan dengan HW-Cell-PECVD nilai konduktivitas terang maupun gelap mengalami peningkatan dari 200-400 mTorr dan selanjutnya turun pada 400-500 mTorr, karena meningkatnya kerapatan cacat pada lapisan.

\section{Sensitivitas Penyinaran}

Sensitivitas didapat dari rasio antara konduktivitas terang dan gelap. Nilai sensitivitas tertinggi $1,33 \times 10^{4}$ untuk lapisan yang ditumbuhkan pada metoda PECVD diperoleh pada tekanan deposisi 400 mTorr, sedangkan lapisan yang ditumbuhkan dengan HW-Cell- PECVD, nilai sensitivitas penyinaran relatif konstan dalam orde $10^{5}$ pada tekanan deposisi 200-400 mTorr. Seperti yang diperlihatkan pada Gambar 5.

\section{SIMPULAN}

ketika tekanan deposisi 500 mTorr dengan lebar celah 1,65 eV sedang pada metoda PECVD lebar celah 1,54 eV pada tekanan 400 mTorr. Meningkatnya Eopt pada tekanan 400 dan 500 mTorr masing-masing untuk metoda PECVD dan HWCell-PECVD disebabkan berkurangnya kandungan atom Ge.

\section{Konduktivitas}

Konduktivitas yang mencakup konduktivitas terang dan gelap pada kedua metoda melalui pengukuran arus-tegangan dengan metoda dua titik (coplanar). Pengukuran menggunakan Fluke 8506A (voltmeter) dan Keithley 617 (amperemeter). Hasil pengukuran dapat dilihat pada Gambar 4. Dari Gambar 4 terlihat bahwa konduktivitas lapisan tipis a-SiGE:H sebagai fungsi tekanan deposisi. Dari gambar terlihat bahwa konduktivitas secara keseluruhan turun dengan meningkatnya tekanan deposisi. Penurunan nilai konduktivitas menunjukkan bahwa rapat rapat cacat dalam lapisan meningkat akibat meningkatnya jumlah kandungan atom Ge. Untuk lapisan
Telah berhasil ditumbuhkan lapisan tipis a-SiGe:H di atas gelas corning 7059 dengan sistem PECVD danHW-CellPECVD. Hasil optimasi menunjukkan bahwa laju deposisi a-SiGe:H lebih rendah dibanding dengan metode PECVD. Laju deposisi meningkat dari 0,31 sampai 1,31 $\dot{A} /$ s dengan meningkatnya tekanan deposisi dari 200 sampai 500 mTorr, laju deposisi relatif konstan setelah 500 sampai 700 mTorr. Lebar celah optik meningkat dari 1,42 sampai 1,65 eV dengan meningkatnya tekanan deposisi 200 sampai 500 mTorr. Sensitivitas penyinaran tertinggi $1,33 \times 10^{4}$ untuk lapisan dengan metoda PECVD, sedangkan pada lapisan yang ditumbuhkan dengan metoda HWC-PECVD relatif konstan dalam orde $10^{5}$ pada tekanan deposisi 200 sampai 400 mTorr. Secara umum terjadi peningkatan karakteristik dari lapisan tipis antara yang di tumbuhkan dengan metode PECVD dengan HWCell- PECVD. Dengan sensitivitas yang mengalami peningkatan dengan orde $10^{5}$ atau lebih tinggi dari syarat minimal orde $10^{3}[5]$. 
[1] Takahasi, K and Konagai, M. Amorphous Silicon Solar Cell (North Oxford Academic Publisher Ltd. London, 1986)

[2] Usman, Ida. Penumbuhan Lapisan Tipis Silikon Amorf Terhidrogenasi Dengan Teknik HWC-VHF-PECVD dan Aplikasinya Pada Divais Sel Surya, Disertasi Doktoral ITB, 2006

[3] Street, R.A. Hydrogenated Amorphous Silikon (Cambridge University Press, Cambridge, 1991)

[4] Amiruddin, S., Usman, I., Mursal, Winata, T. \& Sukirno, Studi Optimasi Parameter Daya RF untuk Penumbuhan Lapisan Tipis
Mikrokristal Silikon dengan Metode Hot Wire Cell PECVD, PROC. ITB Sains \& Tek. Vol. 37 A, No. 1, (2005)

[5] Shima, M., Isomura, M., Maruyama, E., Okamoto, S., Haku,H., Wakisaka, K., Kiyama, S. \& Tsuda, Investigation of Hydrogenated Amorphous Siliocon Germanium Fabricated under High Hidrogen Dilution and Low Deposition Temperature Condition for Stable Solar Cell, Journal Applied Physics, vol.37, Japan (1998) 